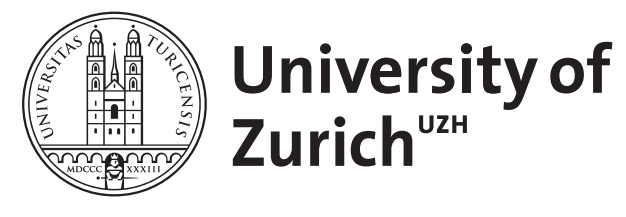

\title{
The normative trap in ethnopolitical research
}

Bochsler, Daniel ; Schläpfer, Basil

\begin{abstract}
Research on ethnic politics deals with politically and socially highly sensitive issues. In this rejoinder, we discuss how research should deal with political and social norms in this field. We agree with Cooley and Mujanovic that researchers should be aware of political and social norms, should try to avoid possible biases, and discuss how their data and results might influence politics and the public debate. We warn against any practice that would lead to self-censorship of research results that conflict with the dominant normative views of scholars or society.
\end{abstract}

DOI: https://doi.org/10.1080/17449057.2016.1190158

Posted at the Zurich Open Repository and Archive, University of Zurich ZORA URL: https://doi.org/10.5167/uzh-130700

Journal Article

Accepted Version

Originally published at:

Bochsler, Daniel; Schläpfer, Basil (2016). The normative trap in ethnopolitical research. Ethnopolitics, 15(5):493-496.

DOI: https://doi.org/10.1080/17449057.2016.1190158 


\title{
The normative trap in ethnopolitical research
}

\author{
Daniel Bochsler and Basil Schläpfer \\ forthcoming in Ethnopolitics
}

Research on ethnic politics deals with politically and socially highly sensitive issues. In this rejoinder, we discuss how research should deal with political and social norms in this field. We agree with Cooley and Mujanović that researchers should be aware of political and social norms, should try to avoid possible biases, and discuss how their data and results might influence politics and the public debate. We warn against any practice that would lead to self-censorship of research results that conflict with the dominant normative views of scholars or society.

The debate about ethnic identification touches upon a highly politicised issue. In Bosnia and Herzegovina, this has lead to years of delay in conducting and publishing the first postwar population census in the country. Our data - distinguishing between four categories Bosniak, Croats, Serbs and a residual category named 'Others' - allows for academic research on topics where these identities matter. In their reply to our work, Cooley and Mujanović point out that our results could be "co-opted by political actors for their own purposes", possibly even by nationalist parties.

Their argument is related to the normative discussion about whether and how ethnic identity distributions in the population should be reported. Certainly, there is no generally accepted model of ethnic relations which would inform us about 'right' or 'wrong' identities. Even advanced industrial democracies differ tremendously in how states and societies relate to their members: since the 1970s the cultural model of the United States and Canada has built on its ethnic communities (Kymlicka 1995, 14-5). In contrast, the French 'republican' model is blind to ethnicity, all citizens are viewed as French above all. In this view, any distinction by identity would divide and discriminate between equal citizens (Jennings 2000).

\section{Addressing the empirical critique}

Regardless of these ideological debates, for empirical research dealing in ethnopolitics and migration studies data on ethnic identities and/or migration background is indispensible. Politics and society will never learn about discriminatory practices against members of certain groups in society if they consider identity groups as a taboo. Hänni (forthcoming) has conducted a worldwide comparative study, in order to measure the impact of political 
representation on the political alienation of ethnic minorities. She also would have liked to measure to what extent Basques and Corsicans are represented in French politics, and whether this leads to their political alienation. However, the French parliament does not publish any data on the identity or origins of its members, nor do opinion polls conducted in France ask questions about identities. This does not mean that no discrimination is practised. However, a society, which considers group identities as a taboo will also be unable to discover if citizens with minority backgrounds are treated unequally.

In post-war societies, ethnicity tends to be an important, if not the most politically salient social category. Hiltmann (2015) has relied on our data in order to study the success of refugee return programs in Bosnia and Herzegovina. As the returns depend on the ethnic context, reliable information on ethnicities is indispensible for any positivist research in this field (for further research questions, see our previous article).

Cooley and Mujanović write that our estimation "uncritically accept[s] the Bosnian state's preferred identity categories" (insert page number). As our critics, we would welcome data which goes beyond over-simplistic ethnic categories, and instead provides nuanced information about multiple layers of identity. Unfortunately, there is no such data on the first two post-war decades in Bosnia and Herzegovina. True, the simplistic political categories, which we use in our research, are only worth considering if they enhance our understanding of social processes in Bosnia and Herzegovina. And true, ethnic maps of the country might be used as a legitimisation of the state policies. However, while politicians fight over the official census results, we can publish results (and discuss the underlying methodology critically). So far as we can judge, our estimations will not get the same political recognition, and are therefore less sensitive. However, they can be used for academic purposes.

We consider that our estimation matches the identities which matter in social and political life in Bosnia and Herzegovina better than any previous numbers. Cooley and Mujanović state that their "intention [...] is not to question the particular method" (p. XXX), but they are suspicious that the nature of the data might lead to a bias towards the politically dominant group. We were also concerned with this issue: we have even reported qualitative evidence (kindly shared with us by Elena Stavrevska) in support of Cooley and Mujanović's concern in our article. As multiple validity tests showed, the effect is small. ${ }^{1}$ The official categories match the identities which matter for social and political life very well. In a survey conducted in 2005 , only 1.5 percent of a representative sample of respondents did not identify either as

\footnotetext{
${ }^{1}$ Under this hypothesis, dominant groups should be over-represented in our data. This would not only imply a homogeneous effect of under-representation of 'Others' across all municipalities, but also that in each municipality, the largest group would be over-represented in our estimation.
} 
Bosniak (Muslim), Serb or Croat (O'Loughlin 2010, 29). The desire to have more nuanced data is thus rather driven by normative than by empirical motives.

\section{Addressing the normative critique}

Normative ideals about (non-)ethnic relations in societies differ widely. In our understanding, empirical research tries to echo normative debates with related evidence, although not necessarily with the goal of taking any normative stances on issues. Cooley and Mujanović write that "new kinds of political movements" leave ethnic categories behind, and thus pursue "a better, more just social order" (cite page numbers). In their view, societies should not be organised along ethnic lines, and thus research on ethnic politics is not needed. In brief, they recommend the study of 'good' movements (e.g. workers' unions, prodemocracy, etc.), and not 'evil' ones (e.g. fascism, nationalists), and/or their consequences. ${ }^{2}$

Academic research does not provide a clear normative answer about using ethnic identities for research. As Kymlicka (1995) convincingly argues, group identities can also be seen as a constituting part of society.

Of course, the political agenda to divide Bosnia and Herzegovina between the three constituent groups has left a horrible scar on Bosnian society, including atrocities aimed at erasing Bosniak life from Eastern Bosnia. Against this background, Cooley and Mujanović's raise valid concerns about the use of the politically recognised identity categories. However, other non-ethnic categories are also politically constructed. Historically, they have been used to weaken the position of the Serbs and/or Croats, and empowered positions which are supported by Bosniak nationalist parties (Bochsler 2012, 70). In the course of the transition from socialism, political quotas included not only Bosniaks, ${ }^{3}$ Serbs, Croats, but also a quota for all 'others', not belonging to the three group. The wartime representative in the government of 'Others', Ejup Ganić, later on joined the Party of Democratic Action, the nationalist party of the Bosniaks. Since the end of the war, the Bosnia has had a three-member presidency composed by a Bosniak, a Croat, and a Serb. The Croat member of the presidency of 2006-2014, Željko Komšić, won votes primarily from places where voters would hardly describe themselves as Croats, and who share their political positions on state issues with the Bosniak parties. While vote-pooling across ethnic lines can support candidates and parties which stand for moderation on ethnic issues, in this case it has raised fears among Croats and Serbs that their interests might be marginalised in the political process. In their perception, the agenda to abandon the rigid, corporatist character of the Bosnian consociation aims at

\footnotetext{
${ }^{2}$ For future research, an online appendix distinguishing good from evil might be helpful.

${ }^{3}$ Pre-1993 addressed as Muslims.
} 
depriving minorities their political rights and protection. Consequentially, it does not strike us as surprising that in surveys, almost all respondents identifying as "Bosnian citizens" also identify as Bosniaks, but hardly any of them as ethnic Croats or ethnic Serbs (O'Loughlin 2010, 29).

There are also empirical and realist arguments in support of a political order which is not entirely blind to ethnic categories. Theoretically, McCrudden and O'Leary (2013, 132-7) explain why peace agreements ending ethnic wars are only possible by recognising ethnic identities, and guaranteeing power to the political elites of ethnic groups. Some empirical evidence suggests that political and territorial separation along ethnic lines reduces the likelihood of future conflict and inter-ethnic violence (Sambanis 2000; Bhavani et al. 2014). ${ }^{4}$ We dare not judge whether deeply entrenched ethnic divisions, or instead the denial of salient identities might be more dangerous and lead to new violence in the long-run.

\section{Avoiding ideological self-censorship}

Last but not least, Cooley and Mujanović warn that ethnic population statistics might serve "primarily to satisfy our own intellectual curiosity, rather than for emancipatory purposes". In brief, they object that the ethnic lens through which we seek to analyse politics in does not fit into the normative canon of the discipline, and of society in Bosnia and Herzegovina. Academics should rather "reflect on role of power and politics in [their] research, however well intended it might be" (p. XXX).

This clashes with our understanding of social science research. Many of our research questions might be motivated by normative goals, but we are also open to accept and publish results which do not fit the ideological mainstream of society and/or our academic peers. After all, ethnicity might turn out to be irrelevant to the understanding of social processes (as might be other politically sensitive categories, e.g. gender, race, religion, abilities, etc.). If we were to refrain from asking questions about such categories, we would never find out.

Empirical research qualifies as scientific because it makes its procedures and data transparent, and accepts the results even though they might be used by political actors, who we personally do not sympathise with. If we are not willing to accept this we cast doubt upon one of the most important good, which we have as academics: credibility.

\footnotetext{
${ }^{4}$ Results remain controversial.
} 


\section{References}

Bhavani, Ravi, Donnay Karsten, Dan Miodownik, Maayan Mor, and Dirk Helbling. 2014. "Group Segregation and Urban Violence." American Journal of Political Science 58 (1):226-45.

Bochsler, Daniel. 2012. "Non-discriminatory rules and ethnic representation: the election of the Bosnian state presidency." Ethnopolitics 11 (1):66-84.

Cooley, Laurence and Jasmin Mujanović. forthcoming. "Population Politics in Bosnia and Herzegovina: A Reply to Bochsler and Schläpfer." Ethnopolitics.

Hänni, Miriam. forthcoming. "Presence, representation and impact: how minority MPs affect policy outcomes." Legislative Studies Quarterly.

Hiltmann, Aleksandra. 2015. "The impact of political and social inclusion on the quality of refugee and IDP return in Bosnia and Herzegovina." In MA thesis. Zurich: University of Zurich.

Jennings, Jeremy. 2000. "Citizenship, Republicanism and Multiculturalism in Contemporary France." British Journal of Political Science 30 (4):575-98.

Kymlicka, Will. 1995. Multicultural Citizenship. Oxford: Oxford University Press.

McCrudden, Christopher, and Brendan O'Leary. 2013. Courts and Consociations. Human Rights versus Power-Sharing. Oxford: Oxford University Press.

O'Loughlin, John. 2010. "Inter-ethnic friendships in post-war Bosnia and Herzegovina." Ethnicities 26-54.

Sambanis, Nicholas. 2000. "Partition as a Solution to Ethnic War: An Empirical Critique of the Theoretical Literature." World Politics 52:437-83. 